\title{
Contestation of 'the holy places in the Zimbabwean Religious Landscape': A study of the Johane Masowe Chishanu yeNyenyedzi Church's sacred places
}

\begin{tabular}{|c|c|}
\hline \multicolumn{2}{|c|}{$\begin{array}{l}\text { Author: } \\
\text { Phillip Musoni }{ }^{1}\end{array}$} \\
\hline \multicolumn{2}{|c|}{$\begin{array}{l}\text { Affiliation: } \\
{ }^{1} \text { Department of Church } \\
\text { History and Church Polity, } \\
\text { University of Pretoria, } \\
\text { South Africa }\end{array}$} \\
\hline \multicolumn{2}{|c|}{$\begin{array}{l}\text { Project leader: Graham A. } \\
\text { Duncan } \\
\text { Project number: } 02618958\end{array}$} \\
\hline \multicolumn{2}{|c|}{$\begin{array}{l}\text { Description: } \\
\text { Philip Musoni is participating } \\
\text { in the research project, } \\
\text { 'History of Theological } \\
\text { Education in Africa', directed } \\
\text { by Emeritus Professor } \\
\text { Graham Duncan, Department } \\
\text { of Church History and Church } \\
\text { Polity, Faculty of Theology, } \\
\text { University of Pretoria. }\end{array}$} \\
\hline \multicolumn{2}{|c|}{$\begin{array}{l}\text { Corresponding author: } \\
\text { Phillip Musoni, } \\
\text { pmusoni@ymail.com }\end{array}$} \\
\hline \multicolumn{2}{|c|}{$\begin{array}{l}\text { Dates: } \\
\text { Received: } 23 \text { Nov. } 2015 \\
\text { Accepted: } 02 \text { Feb. } 2016 \\
\text { Published: } 05 \text { Aug. } 2016\end{array}$} \\
\hline \multicolumn{2}{|c|}{$\begin{array}{l}\text { How to cite this article: } \\
\text { Musoni, P., 2016, } \\
\text { 'Contestation of "the holy } \\
\text { places in the Zimbabwean } \\
\text { Religious Landscape": A study } \\
\text { of the Johane Masowe } \\
\text { Chishanu yeNyenyedzi } \\
\text { Church's sacred places', } \\
\text { HTS Teologiese Studies/ } \\
\text { Theological Studies 72(1), } \\
\text { a3269. http://dx.doi. } \\
\text { org/10.4102/hts.v72i1.3269 }\end{array}$} \\
\hline \multicolumn{2}{|c|}{$\begin{array}{l}\text { Copyright: } \\
\text { (C) 2016. The Authors. } \\
\text { Licensee: AOSIS. This work } \\
\text { is licensed under the } \\
\text { Creative Commons } \\
\text { Attribution License. }\end{array}$} \\
\hline \multicolumn{2}{|l|}{ Read online: } \\
\hline 口fivin: & $\begin{array}{l}\text { Scan this QR } \\
\text { code with your } \\
\text { smart phone or } \\
\text { mobile device } \\
\text { to read online. }\end{array}$ \\
\hline
\end{tabular}

Places that are regarded as holy are highly esteemed in most religious institutions. Such places are revered because they denote the converging points of human beings and the divine. The fundamental questions addressed in this study are: what makes a place holy? Do Christians share sacred places with other religious groups? The study theorises that the Johane Masowe Chishanu yeNyenyedzi Church has forcefully appropriated most of the African indigenous scared places such as hills, shades and dams for all-night prayers and water baptisms. The researcher has selected two indigenous religious shrines; Chivavarira hill and Gonawapotera pool of Chirumhanzu located in the Midlands Province of Zimbabwe. The two shrines are regarded by the indigenes as renowned and sacred. This study analyses and thereto seeks to decode deeper on what makes the Johane Masowe Chishanu yeNyenyedzi Church to enthusiastically appropriate most of the African indigenous shrines and, to some extent, turn them to be their shrines. It is this insight which makes the two shrines to be contested places, especially as perceived from both the indigenes and Christian perspectives. Therefore, this study is a contemporary issue that constitutes the focus of the present concerns. Accordingly, in order to archive the intended goal, this research study relies heavily on participant observation and interviews for data collection, since there is hardly documentation readily available about the Masowe yeNyenyedzi Church in Zimbabwe.

\section{Introduction}

Worldwide, scared spaces serve as focal points in almost all the religious movements. Eliade (1957:26) posited that 'Every sacred space implies a hierophany, an eruption of the sacred that results in detaching a territory from the surrounding cosmic milieu and making it qualitatively different'. Eliade further claims that a sacred place is different from an ordinary space because it is the manifestation of the divine. It must be noted that Eliade regards sacred spaces as sites which are always considered as authentic spaces while the profane spaces are indistinctive without value (Eliade 1957:20). In other words, a sacred place is concrete and permanent site to which generations will point and say, 'this place is sacred and/or holy', while profane space is an amorphous area without quintessence (Eliade 1957:22). This implies that a non-sacred space can be approached without orders, restrictions and prohibitions of certain actions or words; while a sacred place is ordered and distinctive with set rules to be followed. Eliade (1957:28) concluded by saying a sacred space is understood as a place where the divine meets human beings. Therefore, this present study seeks to enquire:

1. What distinguishes a sacred space from profane space?

2. What are the benchmarks the Johane Masowe Chishanu yeNyenyedzi Church employ in choosing its holy places for Church prayer and Baptismal rituals?

3. Do Christian Churches use traditional Religious shrines for their Church services?

With these questions raised, the researcher selected two traditional religious shrines the Johane Masowe Chishanu yeNyenyedzi Church appropriated for church services in Zimbabwe that is Chivavarira hill and Gonawapotera pool which are situated in Chirumhanzu district in the Midlands province of Zimbabwe.

\section{Religious conflict}

This study is about a contemporary conflict between African Indigenous Churches (AICs) represented by Johane Masowe Chishanu yeNyenyedzi Church and/or African Apostolic

Note: This article is a reworked version of aspects of the author's PhD-research, with the theme of 'Inculturated African spirituality: A critical study of the Johane Masowe Chishanu yeNyenyedzi Church spirituality in Zimbabwe', prepared under the supervision of Prof. Duncan, Emeritus Professor, Department of Church History and Church Polity, Faculty of Theology, University of Pretoria. 
Church (AAC) and the indigenes of Chirumhanzu over Chivavarira hill and Gonawapotera pool sacred places in Zimbabwe. The clash started in May 2000 when Chief Chaka heard that a huge group of a white garmented Church had occupied Chivavarira hill; and pitched tents downhill near Gonawapotera pool (W. Mashumba, pers. Comm., 19 December 2014). What disturbed the Chief was that Chivavarira hill is a burial shrine where most of his ancestors were laid to rest. Apart from it being a burial shrine for the Chiefs there is a big sacred cave that the indigenes use for religious ceremonies such as rain or harvest ceremonies. This is how Chivavarira hill became an axis mundi (Eliade 1957:1) to the local people of Chirumhanzu district. Downhill there is a pool in the Shashe River, where locals believe the inhabitants of Njuzu (water spirits) are. Similarly, rain ceremonies are also conducted at that pool by the indigenes of Chirumhanzu. Surprisingly, the Johane Masowe Chishanu yeNyenyedzi and the AAC value the hill and the pool equally the same as the traditional religious practitioners do. These two AICs approach Chivavarira and Gonawapotera traditional sacred shrines with great respect and with great expectations, arguing that the god of the hill and the pool provides solutions to their existential problems (M. Baba Moris, pers. comm., 28 October 2014).

Thus, this study posits that the Masowe yeNyenyedzi Church in Zimbabwe is guided by a theology of 'selective appropriation and continuation'. Unlike other AICs, Johane Masowe Chishanu yeNyenyedzi's most sacred places are those renowned sacred shrines of other established religions, such as ATR in Zimbabwe. Hence this version of theology thrives on possessing already declared sacred places of other religions advocating for a mutual sharing of such places. For them places which were declared sacred by the indigenes of Chirumhanzu will continue to be holy places for religious purposes to all people regardless of religious affiliations. This church is also guided by a 'theology of continuation' in that for them God, who appeared in ancient times in certain places, continues to appear to contemporary people in the same places and will do so to all future generations. Perhaps this is the same reason for conflicts between Christian-Jews and Muslims' struggles over certain sacred places in Palestine (Deborah et al. 2014).

Arguably, while the new faith movements want to use the sacred shrines, the indigenes of Chirumhanzu jealously guard these shrines, claiming them to be theirs; leading into a religious contestation of the Holy shrines in the Zimbabwean religious landscape. Against this background this paper discusses the antagonism that is prevalent between the two rivals, the Church represented by two African Churches Johane Masowe Chishanu yeNyenyedzi and/or ACC and African Traditional Religious Leaders represented by Chief Chaka and the indigenes of Chirumhanzu district over Chivavarira hill and Gonawapotera sacred places. Thus, this study addresses boundaries of religious sacred places.

\section{Religious sacred shrines in Chirumhanzu}

Geographically Chivavarira and Gonawapotera sacred shrines are located in the Chirumhanzu district. This district is at the border of the Midlands and Masvingo provinces. What quickly comes to mind is why the pool and the hill were given such names. This is an old question that will continue to be asked by anthropologists and historians about names and naming concepts, particularly in Africa. The rhetorical question is: 'What is in a name?' Africans, like Jews, give names to places and to children according to hierophanies or certain historical happenings so that they continue to remember the happenings (Anene 2011:1). An example is given of the Biblical Jacob who, after his encounter with the divine at a place called Luz - 'a hard place' - changed it to be Bethel meaning 'the house of God' (Gn 29:35). Likewise, African cultural beliefs are embedded in spiritualism, where names are sacred both for human beings and places (Liseli \& Fitzpatrick 2012:44). For them 'names and naming practice among the African peoples carries spiritual, emotional and physical overtones' (Liseli \& Fitzpatrick 2012:44). Similarly, the hill called Chivavarira situated north-east of the Shashe river was named followed by some happenings. This hill, though looking ordinary from the outsiders' perspective, to the people of Chirumhanzu under the chieftainship of Chaka is no ordinary hill. The hill is characterised by many caves and a very big cave at the centre. According to Chief Chaka in an interview, the caves were originally hiding places for Chirumhanzu residents from tribal Shona and/or Ndebele wars of 1880s which were known by ruthless raiding (J. Chaka, pers. comm., 19 December 2014). He posited that, during those tribal wars, a watchman was selected to watch over the city. If he saw enemies coming from any direction, he would blow a trumpet (hwamanda) and the locals would run to hide in the caves (J. Chaka, pers. comm., 19 December 2014). Thus, the term Chivavarira is a Shona word which can be used interchangeably with the adjective kuvavarira (striving). Literally kuvavarira means striving to get to a place of one' security.

Observably, the study has noted that Chivavarira hill continues to be an icon even after the tribal wars. The hill continues to be given respect due to two important phenomena. Firstly, the indigenes of Chirumhanzu continued to revere the hill for its numerous caves which are now burial shrines for chiefs as indicated earlier. Secondly, the hill continues to be sacred because of the big cave at the centre which is to the indigenes a religious shrine for ancestor veneration. It is because of this phenomenon that the indigenes of Chirumhanzu would by any means possible attempt to prohibit other religious groups to go up the hill for prayers or for any other activities. Cutting down of trees, lighting of fire and game poaching activities are strictly prohibited. Therefore, what is more central in this write up is the big cave at the top of the hill. This cave is central in this study because it is today an attraction for the new religious faiths, Masowe yeNyenyedzi Church and AAC led by Paul Mwazha in Zimbabwe. 


\section{Chivavarira cave}

The Chivavarira cave (Figure 1) can accommodate more than three hundred (300) participants at once according to Chief Chaka in an interview (19/12/2014). Inside the cave are three designed rocks, nicely polished for the Chief and his two bodyguards or machinda a mambo to sit during traditional ceremonies such as praying for rain or mukwerera. There are sacred objects housed in the cave like indigenous tobacco or fodya, religious ancestral clothes or machira emudzimu (some black, white and blue), and wooden plates or ndiro dzematanda and clay pots or mbiya. There are also stones arranged for other male dignitaries to sit during religious ceremonies. The setup of the cave posits that the cave was designed only for religious activities. It is where the indigenes of Chirumhanzu communicate with varikumvepo (ancestors).

In African indigenous religion, caves and mountains are revered. Maxwell (1999:198) observes that mountains are associated with ancestral spirits because they are burial places for the past chiefs. However, this study notes that not all mountains and hills are revered in African indigenous religion. There are specific mountains and hills, particularly those that were declared sacred either by natural happenings or by conversion. Places declared sacred by 'natural happenings' in this study refers to places that are declared sacred due to acclaimed divine manifestations which then make such places to be set apart for religious purposes. And by conversion we refer to ordinary places set aside by human beings for religious purposes. For instance, an ordinary cave ceases to be ordinary after a chief is buried in that cave and an ordinary tree ceases to be ordinary when a certain religious group selected it to be their place for worship. This also applies to buildings: halls which were not originally designed for church services, become holy places from the moment such buildings are hired for church purposes.

\section{Masowe yeNyenyedzi and Chivavarira sacred cave}

The Church Johane Masowe Chishanu yeNyenyedzi was established by Sandros and/or Sanders Nhamoyebonde

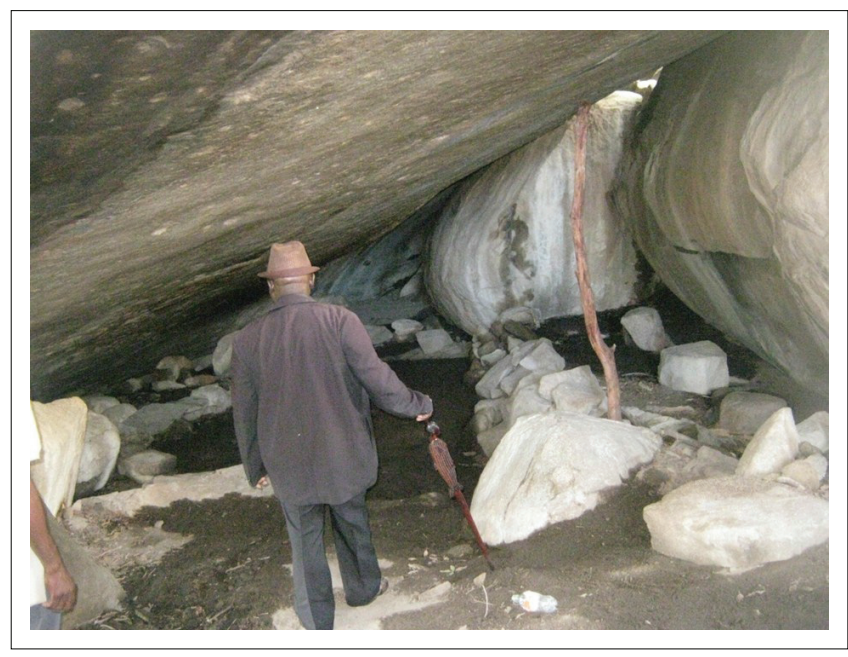

Source: Photograph drawn from author's photo shootings during participant observations on 17 October 2014

FIGURE 1: Chivavarira cave. in the 1990s at the Nyatsime dam in the Chitungwiza province forty-five kilometres east of Harare the capital city of Zimbabwe (S. Baba Gilbert, pers. comm., 15 May 2014). Sandros was a third member in the leadership hierarchy of the original Johane Masowe Church. Shonhiwa Masedza (Johane Masowe) being the founder of this Church died in 1973 of a chronic headache (Dillon-Malone 1978:37). After his death came Mudziwa Dzangara (Emanuweri) who died in 1989 then followed by Sandros Nyamoyebonde (Nyenyedzi) who also died in 1996.

During a prayer retreat at Nyatsime pool, Sandros claimed to have seen a star leading the Johane Masowe Chishanu Church (Engelke 2007). This prayer retreat was done after the second leader from Johane Emanuweri Mudyiwa died in 1989. Emanuweri had promised the Johane Masowe Chishanu that he was going to be raised from the dead like Jesus was raised. Unfortunately Emanuweri did not get resurrected (Engelke 2007). In great desperation, Sandros moved from Guruve to start a new branch of the Johane Masowe Chishanu in the urban centre Chitungwiza Province at Nyatsime dam (G. Baba Amos, pers. comm., 15 May 2014).

The name Masowe yeNyenyedzi was later popularised by Antony Kanengoni after the death of Father Sanders Nhamoyebonde in 1996. At the end of 1997 the newly founded Church moved to Gokwe and stayed there for about two years before they moved to Chirumhanzu in May 2000 (G. Baba Amos, pers. comm., 15 May 2014). According to the interviews the spirit said 'rise go and possess Chivavarira and Gonawapotera in Chirumhanzu' (Prophetess Margaret, pers. comm., 17 May 2014). This is how Masowe yeNyenyedzi took charge of the two sacred places without reversing. All-night prayers are forcefully done in the Chivavarira cave regardless of the sterling efforts by traditional leaders of Chirumhanzu to bar them. In an interview it was disclosed that, on one occasion the leaders of this new faith movement approached the Chief to negotiate on terms and conditions of sharing the hill for religious purposes (M. Chaka [Chief's wife], pers. comm., 19 December 2014). The chief agreed on one condition: that they would not use the sacred cave for their prayers. However, it was reported that the church leaders did not abide by the agreement and proceeded to use the cave. Members of the Masowe Church allegedly reported that they were mysteriously stung by unseen swarm of bees during their prayer meetings (M. Chaka [Chief's wife], pers. comm., 19 December 2014). Members were seen by the villagers running all over claiming to be under attack by stinging bees. It is allegedly reported that they were rescued by the chief's intervention when he went up to the cave and took traditional tobacco and offered it to the ancestors in an African indigenous prayer (M. Chaka [Chief's wife], pers. comm., 19 December 2014).

Despite such mysterious happenings, Masowe yeNyenyedzi and AAC continued to use the cave for their all-night prayers secretly. This is evidenced by ashes the researcher saw in the sacred cave during the second visit on 19 December 2014. 
Our first visit to the sacred cave was on 17 October 2014; and no ashes were evident in the cave then. The Chief testified that there are two religious groups whom he suspected to have done this; these were either the Masowe yeNyenyedzi Church members or the AAC led by Paul Mwazha. For him the two religious groups were a thorn in the flesh. Asking him why he was suspecting the two groups; his response was that the Masowe yeNyenyedzi and AAC members openly informed him that Chivavarira and Gonawapotera shrines are their sources of power for healing and deliverance (J. Chaka [Chief], pers. comm., 19 December 2014). This was supported by a Masowe yeNyenyedzi member in an interview who affirmed these shrines to be their sources of power. For him High God and/or Mwari inhabits the cave and the pool (Baba Godfrey [leader in Masowe yeNyenyedzi Church], pers. comm., 23 August 2014). Thus, this study observes that such claim that Mwari and/or God inhabits African traditional shrines is the central claim in the Masowe yeNyenyedzi Church, particularly in Zimbabwe.

Masowe yeNyenyedzi members are all encouraged to visit the Chivavarira cave in their lifetime and to be baptised in the Gonawapotera pool (Prophetess Madzimai Tsitsi, pers. comm., 12 November 2014). The concept behind this encouragement is that Masowe yeNyenyedzi church members believe that Mwari is found in such places. This assumption is based on the traditional myth that, during tribal raids, a mystical mist used to cover the hill, thus protecting locals who had escaped to the hill for their security. Therefore, the Masowe yeNyenyedzi Church members argue that if one is being tormented by evil spirits and entered into the Chivavarira cave they have escaped from spiritual torments. (Prophetess Paidamoyo, pers. comm., 21 October 2014). Anyone who would enter into this cave is free from evil spirits. 'When you come down the hill, evil spirits will never recognise you; you will be different', said Father Gift (Baba Gift, pers. comm., 24 October 2015). Figure 2 shows ashes that remained in the cave after an all-night prayer, supposedly conducted by Johane Masowe Chishanu yeNyenyedzi or AACs.

Apart from praying in the cave, the Johane Masowe Chishanu yeNyenyedzi and AACs are being accused of vandalising the sacred place by taking bones of long dead chiefs and crushing them into powder (J. Chaka [Chief], pers. comm., 19 December 2014). The immediate question one could ask is, why crush chiefs' bones? This question remains a mystery because no one from either the Masowe or AAC Churches admitted the accusation. However, if the accusation is correct, could one be forgiven to conclude that the crushing of human bones is an example of witchcraft?

The next section deals with the new faiths Johane Masowe Chishanu yeNyenyedzi and AACs appropriating Gonawapotera sacred pool in Zimbabwe.

\section{Gonawapotera sacred pool}

The unprecedented sharing of sacred shrines continues to be a problem among the indigenes of Chirumhanzu.

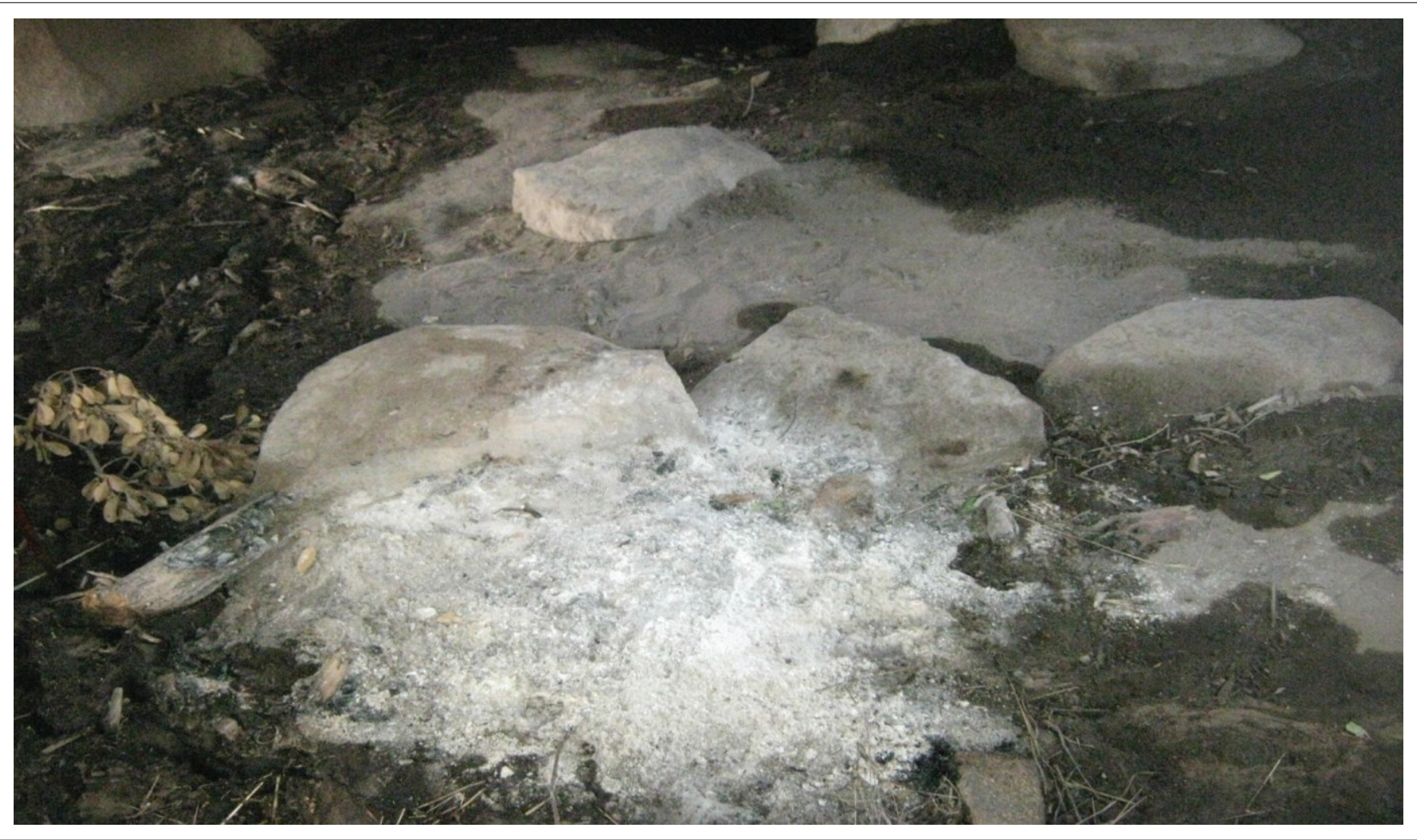

Source: Photograph drawn from author's photo shootings during participant observations on 19 December 2014

FIGURE 2: Ashes in the cave after all night prayer by Masowe Church in Chivavarira cave. 
This sharing of scared shrines has been described as unprecedented in this study because the new faith members Johane Masowe Chishanu yeNyenyedzi Church and the AAC - are not given permission to use these sacred shrines by the rightful owners, the indigenes of Chirumhanzu. Masowe yeNyenyedzi has been allegedly accused of vigorously invading the Gonawapotera sacred pool for baptismal rituals. The pool Gonawapotera is situated in the bordering river Shashe that separates two provinces Midlands and Masvingo in Zimbabwe. Gonawapotera sacred pool therefore is on the right side of the Shashe Bridge as one will be driving from Harare to Beit Bridge (Figure 3).

According to Chief Chaka in an interview, the name Gonawapotera carries a lot of old memories. Criminal offenders such as witches, sorcerers, thieves and adulterous used to be drowned in the pool as death punishment. Thus, the name Gona-wapotera literally means 'if you have done something wrong, go to someone for vindication'). What it implies is that these criminal offenders should not wait to be taken to court (Chief's court), but to accept guilt and seek help before one is drowned in the pool 'Gona-wapotera.' What I gathered from the interviews is that criminal offenders who accept guilt at once were given a lighter punishment than those whom the chief through his wisdom found guilty.

A long wide underground tunnel was dug and built by Chirumhanzu residents around 1880s. This tunnel connects Chivavarira hill with the Gonawapotera pool. It was through this long and wide channel that the blindfolded offender would be taken to be drowned in the Gonawapotera pool (J. Chaka [Chief], pers. comm., 19 December 2041). The pool is said to be very deep so that a blindfolded and handcuffed offender could do nothing to save himself from drowning in the deadly pool.

Also, besides its depth it is believed that the pool inhabits Njuzu (Water spirit). According to Chief Chaka, if the accused were not guilty of the accusation and were thrown into the pool, the Njuzu or water spirit would save them from drowning and the relatives would find the them alive the next morning near the pool with their hands bound and blindfolded, the same way they were thrown into the pool (J. Chaka [Chief], pers. comm., 19 December 2041). This testimony was also confirmed by Ignatius Zvarevashe in his Shona novel Gonawapotera, where he talks about a certain young man who was appointed to be the next Chief. Jealousy grew among the family members and the young man was thrown into the pool. However, before he was thrown, the traditional leaders of that time had assured the Chirumhanzu members that, if the boy was the rightful candidate, the water spirit would save him, but if not, he would die in the pool. It is allegedly reported in that novel that the young man was found the next morning sitting on a big rock in the middle of the pool (Zvarevashe 1978:16). Thus, the pool was given the name Gonawapotera, sending a message to lawbreakers that they should accept guilt and pay a lighter penalty than to be thrown into the pool as a death sentence.

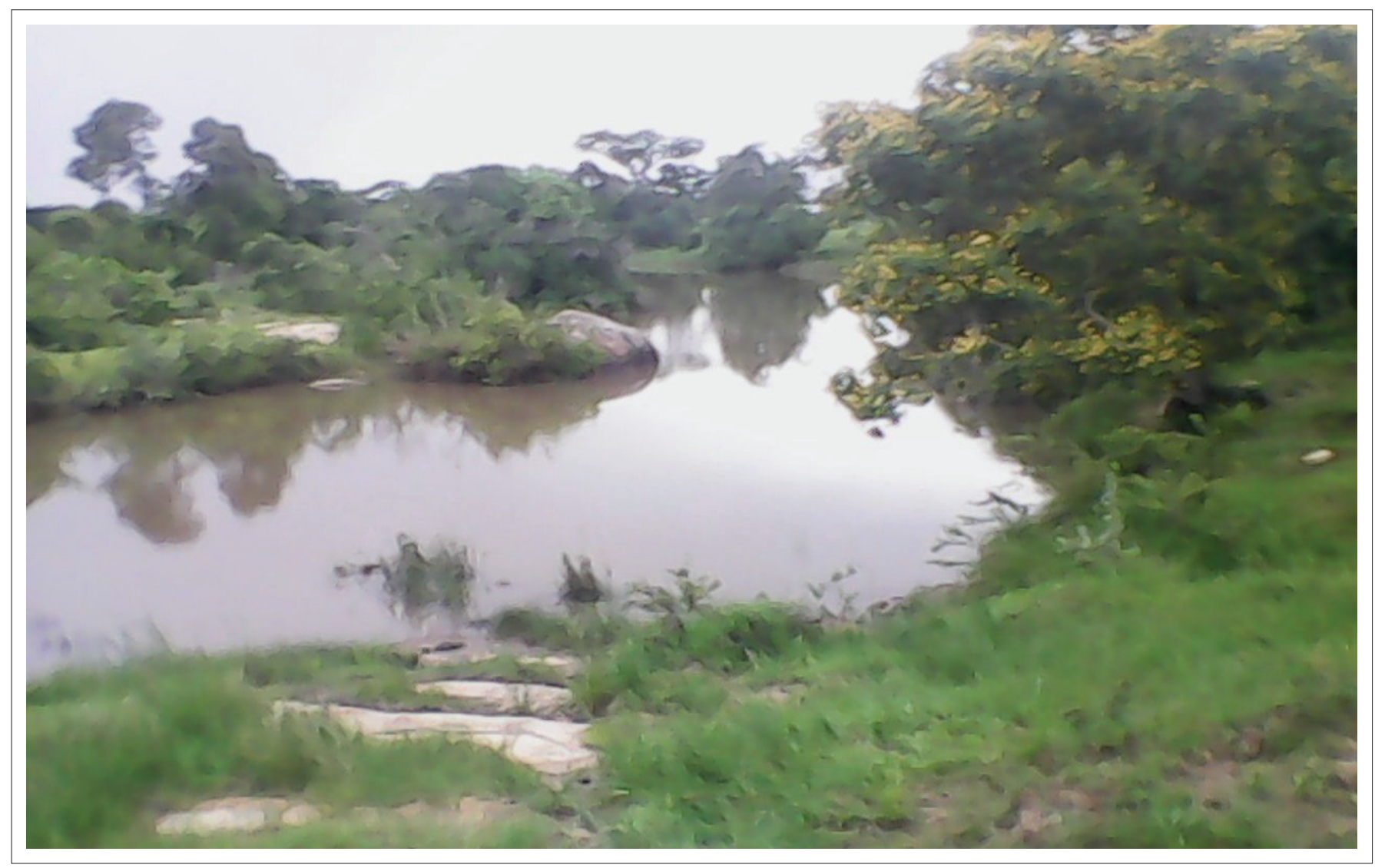

Source: Photograph drawn from author's photo shootings during participant observations on 17 October 2014

FIGURE 3: Gonawapotera sacred pool in Shashe River, Chirumhanzu. 
This pool is sometimes referred to as 'Ndarikure, Murwizi munaShashe, Govera raChirumhanzu, ugaro hwowamasimba ose, Kutebhanekari'(Anon 2015).

This study has noted that the pool continues to be sacred because of the water spirit believed to inhabit there. Therefore, like the Chivavarira cave, the people of Chirumhanzu revere the Gonawapotera sacred pool. Traditional gatherings are done at these two shrines. During such gatherings, spirit mediums would go down into the deep ends of the pool; spend hours under water and would come out with a claimed prophetic word from the Water Spirit (J. Chaka [Chief], pers. comm., 19 December 2014). The community members are not allowed near the pool; neither to do fishing nor laundry. The pool only serves for traditional gatherings. Stories are told that on many instances villagers sporadically could see clothes lying on rocks and upon wanting further verification of the happenings, clothes would mysteriously disappear. It is in this pool that Masowe yeNyenyedzi/ AACs secretly baptise their church members.

\section{Masowe yeNyenyedzi Church baptism at Gonawapotera}

This study has noted that Masowe yeNyenyedzi Church uses the pool for their baptismal rituals. Asking leaders of this church why baptismal rituals in Masowe yeNyenyedzi Church are done in such dangerous pools, the response was that baptism is a sacred event that cannot be conducted in an ordinary river or pool. Members are baptised in these waters so that they come out of the waters equipped with sacred powers from the Water Spirit (Prophetess Madzimai Majory, pers. comm., 22 October 2014). The witnessing of a Masowe yeNyenyedzi water baptism at Gonawapotera on 24 October 2014 was a learning and exciting event. Some prophets or vakokeri vemweya were selected to go in advance to the pool to persuade the Water Spirit to allow them to baptise their new converts. Once the prophets confirmed that varidzi vedziva vabvumidza rubabhatidzo (the owners of the pool, meaning the Water Spirits, have allowed water baptism), the leaders would immediately organise the people for baptism. During that fore mentioned observation the Masowe yeNyenyedzi's national Leader Father Ndaidza Tawanda was the one on vanguard together with a host of prophets and prophetess who formed two long parallel lines in the pool. Members were asked to kneel facing east and sing Hosanna! Hosanna! After the long chorus everybody was asked to be quiet in order to hear what the spirit was going to say through the leader Baba Tawanda Ndaidza:

Tauya pana Shashe (we have come at Shashe River)

Panzoimbo inoyera (a very sacred place)

Farai nokuti masvika pana Shashe (rejoice for you have come at holy place)

Apo ndudzi yomutema ino babhatidzwa (where Africans are baptised)

Joridhani repana Shashe rinoera( baptism at this place is sacred)

Takumbira varidzi vedziva kuti tiite rubhabhatidzo (we have negotiated with the owners of the pool 'Water spirits')
Tapiwa mahawa matatu (three hours have been allocated to us to do baptism)

Saka toita basa redu nekukasika( so let's be fast in whatever we are doing here)

Rufaro kwamuri, Rufaro kwamuri, Rufarooooooo (joy unto you X3) [church slogan].

This study posits that the Johane Masowe Chishanu yeNyenyedzi Church is deeply rooted in African spirituality. By African spirituality here in this study, we refer to the Karanga people of Chirumhanzu ways of approaching and celebrating the ultimate-concern that pre-dates missionary Christianity in Zimbabwe. Before European missionaries came to Africa particularly in Zimbabwe, Gonawapotera, Chivavarira and Matonjeni hill among others were religious centre for veneration of Ancestors. Religious leaders used to go there for rainy ceremonies. Thus today we see the Johane Masowe Chishanu redefine and revive these old traditional sacred shrines for Church rituals hence influenced by Traditional Africans ways of approaching the divine.

\section{Masowe yeNyenyedzi and African spirituality}

This study posits that the spirituality of Masowe yeNyenyedzi and AACs should be scrutinised because of their radical beliefs and teachings particularly when it comes to appropriation of African Traditional shrines for Church prayers and rituals. Our analysis of Masowe yeNyenyedzi Church spirituality in Zimbabwe shows that African spirituality continues to feature prominently in these new faith movements in the Zimbabwean religious landscape. Thus, this study posits that the Johane Masowe Chishanu yeNyenyedzi and AAC are deeply influenced by Africans and/or Karanga people of Chirumhanzu's various ways of expressing their experience of God (Orobator 2008:142). Chitando and Mateveke (2014:136) observe that the association between some AICs and African mysticism remains exceedingly controversial. These two scholars further raised the following rhetorical questions:

Have AICs failed to promote radical conversion by continuing to uphold the indigenous worldview? Have AICs demonstrated theological sophistication by reinterpreting indigenous beliefs and practices in the light of the new faith? (Chitando \& Mateveke 2014:136)

Against this backdrop the researchers of this study postulates that Masowe yeNyenyedzi and the AACs spiritualities need further studies. While other AICs in Zimbabwe build houses of worship, the two AICs forcefully grab other religions' sacred shrines as seen in this case study of Chivavarira and Gonawapotera in Chirumhanzu, Zimbabwe. For them Mwari is not found in a house built by men such as elaborative and expensive temples (Mukonyora 2007), but God is found in a thick bush, in deep caves, and in dreadful pools. Accordingly sacred shrines like Matonjeni, Matopo hills and Chirorodziva among others continue to attract AICs particularly the Johane Masowe Chishanu yeNyenyedzi and AACs in Zimbabwe. 
However, for a long time the dominant mode of identity for Masowe Churches has been focused on sacred wildernesses (Mukonyora 2007:18). Surprisingly, for the Johane Masowe Chishanu yeNyenyedzi Church sacred places are those renowned traditional shrines, such as sacred caves and pool; sacred trees such as muhacha and mukondekonde and graveyards.

This study argues that the Masowe yeNyenyedzi Church in Zimbabwe's appropriation of traditional sacred mountains and caves represents an unusual church spirituality. On recent studies the Zimbabwe Herald newspaper allegedly reported another similar incident where a traditional healer and a Masowe prophetess use Mountain - Mawanga for religious purposes. This mountain is known as renowned sacred shrine for the indigenes of Goromonzi from time immemorial. People from all walks of life come to this mountain for healing and exorcising of demons (Kawadza 2015). Mawanga Mountain which stretches from Chakabvapasi and Mushayapekuvaka villages in Goromhonzi district in Mashonaland central province is a centre of attraction drawing people from all walks of life to come for spiritual nourishment. According to the Herald of 24 February 2015, on one end of the mountain was a lady Masowe prophet and on the other end of the same mountain was Sekuru or Spirit Medium and both were drawing equally huge crowds (Kawadza 2015). The prophetess Madzimai Tabeth whose real name was Marjory Charuma confessed that she was using the power that was coming from the sacred mountain to heal the sick and exorcising demons.

\section{Cleansing ceremonies (mapira) of sacred shrines in Chirumhanzu}

The study observes that after the Masowe yeNyenyedzi Church used the shrines, the Indigenes of Chirumhanzu organised cleansing ceremonies. The Chief of Chirumhanzu organised such ceremonies to clean up their religious shrines Chivavarira hill and Gonawapotera pool after they were used by these new faith movements - Masowe yeNyenyedzi and AACs in Zimbabwe. According to the Chief, cleansing ceremonies were necessary to appease the angry spirits. The first Ceremony was held on May 2014 and the second was held on 24 September the same year. Spirit medium were invited from various places, including some from Chipinge, Mhondoro, Chiweshe and Gokwe to come and cleanse the shrines. According to the interviews Chief Chaka reported that on 24 September a total gathering of 26 masvikiro or Spirit Mediums and few religious leaders from Chirumhanzu spent the whole night in the cave. Beer was brewed and was drunk in the cave with a lot of activities taking place till the following morning. The villagers joined this small group to the pool 'Gonawapotera' early morning. Playing of traditional drums, pouring of beer and traditional snuff again took place at the pool during the big gathering on the 25 September 2014 (Interview: Chief Chaka 19/12/2014). Twelve masvikiro were selected to go under water to appease the angry Water Spirit said Chief Chaka. Further Chief Chaka informed the researcher that on that occasion these selected twelve Spirit Mediums stayed about one hour under water (Interview: 19/12/2014). Mr. Mhazi- the Chief's board guard testified that after the September ceremony, around midday the Chirumhanzu residents witnessed a rainfall, a sign to them that the cleansing ceremony was a success (Interview: Mhazi 19/12/2014). This was also supported by Masimba a villager of Chirumhanzu that soon after the ceremony the residents experienced heavy rainfall (T. Masimba, pers. comm., 19 December 2014). The Chief also informed the researcher that plans to fence the Chivavarira hill were at an advanced stage. He highlighted that the idea of fencing was triggered by these Masowe and/or Mwazha Churches vandalising the sacrality of the hill by crushing long dead Chiefs bones and forcefully using the sacred cave among other things.

\section{Conclusion}

This article has discussed some contestations associated with Masowe yeNyenyedzi Church and the indigenes of Chirumhanzu over two sacred shrines: Chivavarira hill and Gonawapotera pool in Zimbabwe. The study notes that the Masowe yeNyenyedzi Church represents an unusual spirit of inculturation by appropriating African traditional sacred places for Church services. Generally, inculturation is concerned with incarnating the Christian Gospel message in time (Nyamiti 1973:29). For Nyamiti inculturation as a process create interaction of the compatible local cultural elements and the Gospel in such a way that the believer feelsat home in their culture and in the church (Nyamiti 1973:29-30). Contrastingly, it is interesting to note that the Johane Masowe Chishanu yeNyenyedzi Church instead of fusing the Gospel message with compatible local cultural elements, has actually replaced Christian spiritual element of faith such as; the work and person of Jesus Christ for salvation by the mysterious powers from Water Spirits (Njuzu) and the distortion of the meaning of water baptism into initiation of members into mystical powers of water spirits. Accordingly, Masowe Chishanu yeNyenyedzi's lack of a clear doctrine of Christology has been an important criterion in this study to arrive at a conclusion that this Church has moved away from being authentic Christian Church to just another New Religious Movement (NRM) in Zimbabwe. For that reason, this study recommends that in the process of Gospel inculturation caution should be employed to avoid overstepping certain religious boundaries especially those that define and separate one religion from the other.

\section{Acknowledgements Competing interests}

The author declares that he has no financial or personal relationships which may have inappropriately influenced him in writing this article.

\section{References}

Anene, E., 2011, African best baby names, Author House, London.

Anon, 2015, 'Ndarikure, tebenakeri yowaMasimba ose, murwizi munaShashe', viewed 11 December 2015, from http://.www.social-peek.com/keywords/ndarikure.html 
Chitando, E. \& Mateveke, P., 2014, 'Shifting perceptions: African initiated church groups and Gospel music in Zimbabwe', in E. Chitando, M.R. Gunda \& J. Kugler (eds.), Multiplying in the spirit: African initiated churches in Zimbabwe, pp. (eds.), Multiplying in the spirit: African initiated
129-144, University of Bamberg Press, Bamberg.

Deborah, F., Shmueli, N., Collins, K. \& Michal, B.G., 2014, 'Conflict over sacred space: The case of Nazareth'. Cities 41(1), 132-140, viewed 14 August 2015, from http:// www.linkinghub.elsevier.com/retrieve/pii/S0264275114000997.html

Dillon-Malone, C., 1978, The Korsten basketmakers: A study of the Masowe Apostles, an indigenous African religious movement, Manchester University Press, Manchester.

Eliade, M., 1957, The sacred and the profane: The nature of religion, Harcourt Press, New York.

Engelke, M., 2007, A problem of presence: Beyond scripture in an African church, University of California Press, Berkeley, CA.
Kawadza, S., 2015, '1 mountain, 2 religions', The Herald, 24 February, p. 4.

Liseli, A. \& Fitzpatrick, B.A., 2012, African names and naming practices: The impact slavery and European domination had on the African psyche, identity and protest, Ohio University Press, Athens, $\mathrm{OH}$, viewed 13 October 2015, from https://etd. ohiolink.edu/rws_etd/document/get/osu1338404929/inline.html

Maxwell, D., 1999, Christians and Chiefs in Zimbabwe: A social history of the Hwesa people c 1870s-1900s, Edinburgh University Press, Edinburgh.

Mukonyora, I., 2007, Wandering a gendered wilderness: Suffering \& healing in an African initiated Church, Peter Lang Press, New York.

Nyamiti, C., 1973, The scope of African theology, Gaba Publications, Kampala.

Orobator, A.E., 2008, Theology brewed in an African pot, Orbis Books, Maryknoll, NY. Zvarevashe, I., 1978, Gonawapotera, College Press, Harare. 